\title{
Political legitimacy and crisis management in the Economic and Monetary Union: a model of democratic governance
}

\section{Gabriele De Angelis}

To cite this article: Gabriele De Angelis (2016): Political legitimacy and crisis management in the Economic and Monetary Union: a model of democratic governance, European Politics and Society, DOI: $10.1080 / 23745118.2016 .1229388$

To link to this article: http://dx.doi.org/10.1080/23745118.2016.1229388

曲 Published online: 11 Oct 2016.

Submit your article to this journal $\widetilde{ }$

Џ Article views: 36

Q View related articles $\sqsubset$

View Crossmark data $\nearrow$ 


\title{
Political legitimacy and crisis management in the Economic and Monetary Union: a model of democratic governance
}

\author{
Gabriele De Angelis \\ IFILNOVA, Faculdade de Ciências Sociais e Humanas, Universidade Nova, Lisbon, Portugal
}

\begin{abstract}
The euro and sovereign debt crisis is both a conflict of political and economic interests and a conflict of interpretations. Two narratives struggle for hegemony in the European ideological imaginary. Each calls for a different mode of crisis management, and each represents a different vision of the single currency, European economic and monetary policy, and European integration as a whole. Each presents different theses on the origins and causes of the crisis, as well as its solution. As important as it is to know which narrative provides a correct interpretation of the crisis in macroeconomic and monetary terms, both remain insufficient when it comes to solving the political and ethical conundrum facing Eurozone governance and the management of the sovereign debt crisis. In fact, both paradigms mirror the economic and political interests and legitimate ethical expectations from the standpoint of which their proponents approach European integration. To understand these expectations, it is therefore necessary to enquire into the conditions of fairness that might allow for legitimate crisis management. The paper attempts to do so while also presenting a model of democratic governance for the Economic and Monetary Union.
\end{abstract}

\section{KEYWORDS}

Economic and Monetary Union; political legitimacy; European governance; democratic accountability; euro and sovereign debt crisis

\section{Moral economics and economic nationalism: the pro-austerity narrative}

Austerity politics rests on the idea that fiscal indiscipline -that is, excessive deficit and debt - is the genuine cause of the crisis. The 'budgetary indiscipline' theory is sometimes articulated in a (harshly expressed and surely oversimplified) version according to which some members of the Economic and Monetary Union (EMU) continue to maintain a level of expenditure not supported by their actual economic performances, baldly exploiting the industriousness of their more disciplined partners (Kerber, 2012; see also Guérot, 2013) and leaving to the latter the task of achieving price stability.

Some commentators dress the question in anthropological terms, theorising about different political and economic cultures of efficiency, public spending, tolerance for deficit, etc. (Henkel, 2010; Richter, 2012) and claiming that the European peoples display cultural differences so great as to make economic convergence impossible. A more sophisticated version of the culturalist interpretation of the euro and sovereign 
debt crisis identifies a clash between the German 'ordo-liberal' vision of an ideally politicsfree management of the EMU and an 'opportunistic' attitude that bends EMU rules to political convenience and the choices of its members. On the ordo-liberal view (van Esch, 2014, pp. 289-290; Young, 2014, pp. 279-280), the EMU should rest on justiciable criteria. Ordo-liberal critics of the crisis's management underscore the excessive flexibility with which the common rules have been interpreted, as was the case when the Treaty's ban on bailouts, ex-Art. 125, was bypassed to help indebted countries (Joerges, 2012, p. 1016). The motivation for avoiding bailouts is both ethical and political, and has only indirectly to do with the strict financial sustainability of the euro system: EMU rules are designed to foster members' individual responsibility for their own financial equilibrium, instead of drawing off of their partners' 'fiscal virtue'. Bailouts undermine the moral incentive to persevere on the virtuous path (or to first embark on it) and elicit deviation.

As a matter of fact, austerity is advocated at least as much for its disciplining political effect as for its connection to actual economic theory. With that said, several supporters of austerity also mention structural explanations for the fiscal indiscipline of some EMU members: defective implementation of budget coordination generates the wrong incentives for governments, thus inducing 'weaker' members to engage in budgetary disorder and consequent free riding at the expense of the virtuous (Baimbridge, Burkitt, \& Whyman, 2012). The EMU itself has watered down the incentives to foster international competitiveness that are usually set for national economies by currencies and interest rate fluctuations. Weaker countries have therefore postponed urgent reforms (e.g. in the labour market), and structural differences have consequently widened rather than narrowing (Tilford, 2010, p. 3). Of note is the opinion of scholars from indebted countries who pay tribute to the ordo-liberal view, acknowledging that the single currency has facilitated capital flows to the point of concealing the need for weaker countries to undertake structural reforms, such as efficiency in the public sector, innovation in the private sector, and welfare state sustainability (on Spain, see Pomés, 2012, p. 201).

A less generous interpretation charges indebted countries with the explicit intention of free riding on others' virtue in order to live 'above their means' via irresponsible deficit spending (e.g. France, among others), by allowing salaries to grow far above increases in productivity (Portugal and Greece), and by failing to redress inefficient fiscal systems (Italy). On this line of interpretation, a negative balance of trade, which almost all European partners have had over the years relative to Germany, is not the result of 'rational' economic behaviour dictated by given market conditions but an expression of collective ill will. Were indebted partners less inflation friendly, their balance of trade would look better (Kundnani, 2012).

Although the debate often drifts towards cheap psychology, the diatribe about crisis management is not only about the emotional urge to discipline one's neighbours or the embarrassment of being in the same boat as ungoverned (or, to pick up the other side of the cliché, overly rigid), 'culturally different' neighbours (Sarrazin, 2012a, 2012b) indeed, this is not even the main or most interesting part of it. In fact, the stability of the common currency, in particular price and exchange rate stability, has been a common concern from the start. This is due not least to the specific ordo-liberal interpretation that has been given of the conditions under which the common currency would have been successful. At the root of the idea of a common currency lies the notion that the fiscal and budgetary effects of public legislation impact on the price of one's own 
currency. Under a common currency, just as any country is 'rewarded' or 'punished' for its public policies in terms of currency value, inflation, and interest rate stability, any EMU member's fiscal and budgetary behaviour impinges on other members' stability terms. However, since in the face of a plurality of EMU members the actions of any member have diluted effects on currency and macroeconomic conditions, free riding with regard to others' budgetary virtues is an ongoing temptation. Although some authors are ready to acknowledge that supposedly virtuous countries did not refrain from profiting from their partners' 'lack of discipline' (e.g. French and German banks with respect to Greece's excessive levels of public and private debt) (Kirsch, 2010), effective reciprocal control over national budgetary behaviour - and therefore the acceptance of a corresponding loss of budgetary sovereignty - is the linchpin of the common currency. When the common budgetary rules are disrespected, the common currency's stability is endangered and the virtuous countries unfairly burdened with the consequences of others' failures. If members states' economic and budgetary paths diverged and competitiveness gaps grew instead of diminishing, this is due to the differing budgetary preferences of EMU members, which makes clear that the common rules and their faltering implementation were not apt for preventing their respective governments' inconsistent behaviour. The fact that the ECB was called on to support states' budgets - contrary to its original task and intentions - is a threat to its independence and to the very logic of the EMU. On this view, the Eurozone is not the place to exert European solidarity (the Structural Funds must be sufficient for this), for the common currency is not supposed to smooth out gaps of competitiveness, especially when competitive advantage is the deserved reward of a country's hard-fought virtue (Ohr, 2012, pp. 26-27).

In the light of these assumptions, austerity seems to be a means of fostering budgetary equilibrium, external conditionality its most promising means of enforcement. The socalled Troika's direct control over the budgets of countries that have received financial assistance and the European Commission's preventive control over members' budgetary laws - to which must be added the continuous control exercised by the ECOFIN and the Eurogroup - serve to bring national politics under the supervision of supposedly neutral, 'technical' institutions, to the effect that the rules are implemented in the absence of supposedly 'opportunistic' interference.

In sum, the pro-austerity narrative supports a consistent transfer of sovereignty in matters of public budgeting in the name of the idea of an EMU, according to which some members shoulder the entire responsibility for catching up with those who are more competitive and virtuous. Since the fiscally virtuous countries need fewer fiscal restraints than their less virtuous fellow members, both the transfer of sovereignty and the required fiscal effort are also ultimately asymmetrical: they will weigh on some EMU members to a far greater extent than others. The underlying conception is that the EMU ought to leave the gaps in competitiveness between members unaltered. If the common currency elicits macroeconomic convergence, this will happen indirectly through a country's recognition of its defective competitiveness relative to its partners and with the consequent individual effort to catch up - rather than directly, through instruments that actually promote economic convergence (with the exception, of course, of the Structural Funds). The political choice underlying this way of implementing the common currency is evident: the EMU is not supposed to impinge on the means of political influence and prestige among countries, which in Europe are mostly economic. 
In the context of this non-political conception of the EMU, political legitimacy does not become an issue at all, or else the issue is resolved once the signatories have accepted the common rules as part of an international agreement. Further democratic processes following ratification are not part of the game. On the contrary: the shifting political will of sovereigns is precisely what must be kept at bay if fiscal discipline is to be secured in the future.

\section{A common currency without a common fiscal policy? The anti-austerity narrative}

Alongside the 'moral(ist)' interpretation of the sovereign debt crisis, a considerable number (perhaps even the majority) of observers of European economic developments have construed the crisis as having been set off by competitiveness gaps, which the rules of the EMU sharpened substantially and which acted as a trigger for the financial crisis of 2008-2009. Even prior to the signing of the Maastricht Treaty, critics warned that relinquishing monetary sovereignty would make it more difficult for national economies to adapt to the common market (Godley, 1992/1997). In the international market, currency adjustments - or, wherever currency fluctuations are limited, interest rate adjustments - are a mirror of different economic performances. Besides giving market players and governments reliable information on how to react to changing market conditions, they also allow for the progressive adjustment of national economies to evolving gaps in competitiveness. Once currency values cease to be signals of economic performance under a regime of fixed currencies (or of a single currency), the only remaining means for adjusting to changing market conditions are internal devaluation (i.e. the rise and fall of salaries and prices), workforce migration, and public fiscal intervention. In the EMU, however, fiscal intervention is limited by common budgetary rules. Since salaries and prices are slower to adjust than currency values, GDP and employment are (at first) those factors most affected by the changing economic environment. Competitiveness gaps will result in declining GDP and spreading unemployment (Feldstein, 1992).

Of course, central banks also play an important role in influencing a country's economic performance. However, the ECB's exclusive mandate to target inflation rates - recently extended by Mario Draghi's innovative (and politically welcome, though controversial) interpretation of the Statute - and the inescapable rigidity that comes with having a single discount rate for 19 countries with different internal inflation and employment rates will not help to restore common market equilibrium. ${ }^{1}$ The theory of 'optimum currency areas' that lies behind the common currency (Mundell, 1961) therefore suggests that in a regime of fixed exchange rates (or of a common currency, which amounts to the same thing) the mobility of production factors (labour as much as capital) is just as important as the flexibility of prices and salaries when it comes to the ability of the workforce to pursue opportunities where production is growing and to leave areas of declining production (Dinan, 2010, p. 88; Feldstein, 2010, p. 11). However, prices and salaries (themselves a component of prices) are in practice less responsive to market conditions than currency values. Adaptation is therefore slower. ${ }^{2}$

Current hypotheses about the roots of the crisis therefore point to trade imbalances encouraged by inflation rate differentials - as being decisive. ${ }^{3}$ In the Eurozone, prices have not in fact followed the competitiveness gap due both to the different inflationary impact 
of the ECB's interest rate on the economic cycles of the member states and to national economic choices (in particular, the wage restraints agreed on by German employers and unions in the late 1990s) (De Grauwe, 2012, p. 176; ECB, 2005; Esser \& Schroeder, 1999). While the nominal interest rate was of course the same for all EMU countries, the real interest rates were low in countries with relatively higher growth and increased inflationary risks (such as Spain) and high in countries with diminished growth and low inflationary risks (such as Germany). This led to an influx of cheap capital and subsequent speculation bubbles in the first case and to a further phase of lagging economic growth (Arfara, 2012, p. 17) in the latter. The growth in GDP experienced by the former group was largely illusory insofar as it rested on the dynamic of capital influx rather than increases in productivity and efficiency.

In such a context, the absence of economic coordination between EMU member states has crucial consequences. Indeed, as long as the increase in a country's competitiveness and ability to hold a positive balance of trade does not result in increased consumption and rising inflation - which would help balance out the terms of trade in the long run it will lead, to the contrary, to augmented capital flows and subsequent financial bubbles in less competitive countries. Bubbles have thus been the flip side of trade imbalances and free capital flows in the euro area. Crisis-ridden countries have in fact been characterised by relatively high inflation (due to constant capital influx rather than effective and sustainable growth). The 'explosion' of financial bubbles has therefore been the actual trigger, but not the 'deep cause', of the euro and sovereign debt crisis.

To be sure, the financial trigger itself goes back to the in-built flaws of the EMU. When recessions hit and deficit and debt figures begin to increase, investors foresee the hardships likely faced by countries given the relative inflexibility of EMU rules and react with a 'sudden stop', that is, by de-investing in them. The subsequent rise in interest rates sets off a financial spiral (the same applies when market operators start guessing about 'who's next'). Again, not only were the EMU rules not apt for fending off this threat, ${ }^{4}$ but they put member states in a conflict of interest with one another insofar as the rise of one's interest rates signified a fall in the other's (because investors saw the other as a 'safe haven' for investment). Contingent financial triggers to the side, however, the fact remains that under the conditions of monetary union neither currency adjustments nor discount rate fluctuations, and least of all a coordinated economic policy, were available to balance out the diverging economic paths of EMU members.

Austerity - with all the social distress that follows from it - is in the end merely a political means of bringing about what free market mechanisms failed to achieve, that is, the adaptation of prices and salaries to productivity and inflation gaps. Reduced consumption and sinking (or slowing) salaries are meant to restore the equilibrium of the balance of trade as an alternative to (no longer possible) currency adjustments. The social costs are therefore not mere side effects of austerity politics, but rather their central intended consequences.

In addition to its social costs, however, austerity has a number of further unintended consequences. Adaptation through internal devaluation indeed increases a country's financial fragility: once prices drop, the real value of debt increases. Growing external competitiveness, which is the ultimate aim of internal devaluation, is remarkably slow to substitute internal consumption. The depressed internal demand therefore results in a declining overall GDP, which in the short term worsens both the deficit-to-GDP and the debt-to-GDP ratios. Pressure on budgets will therefore continue, as we witness today 
both in countries that have been bailed out and in countries that have had a tough time complying with the Maastricht criteria, such as Italy.

There is much evidence to support this vision of the causes of the crisis. First is the fact that most crisis-ridden countries had relatively modest deficit-to-GDP and debt-to-GDP ratios prior to $2009 . .^{5}$ Second, their balances of trade were negative in the previous decade. ${ }^{6}$ Furthermore, each crisis-ridden country had its own specific weaknesses, and each of them wound its own path into the crisis: those in which financial or real estate bubbles were stronger suffered bank collapses, the cost of which, once the bubbles exploded, was promptly socialised and turned into a budgetary crisis through governmental intervention. Those that had suffered from a slow but steady decline in competitiveness and scarce economic growth, such as Italy, had to face market pressure on public debt once the markets realised the euro-connected risks in the light of the course of austerity steered by Europe (Busch, 2012, pp. 16-29; Enderlein, 2010).

In sum, the anti-austerity narrative effectively questions the core assumption of austerity politics, which is the key role played by public debt, and points instead to private debt, and especially external debt, as a consequence of massive capital influx. When it comes to the root causes of the crisis beyond the 2008-2009 financial shock, international trade imbalances - and their specific consequences under the current EMU structure - are thus likely candidates. The easy objection that the crisis-ridden countries have deep public sector inefficiencies and sometimes worryingly unbalanced public budgets - as with Greece and Italy even before 2009 (although, again, the argument does not apply to Spain or Portugal) - is not as strong an argument as it first seems, for an economic area without productivity and price gaps is as unthinkable as a market economy without inequality. The EMU must therefore have sufficient means to face these imbalances (which does not prevent the euro partners from requiring members to pursue well-balanced fiscal and budgetary policies and to improve public sector efficiency).

As follows from the above considerations, austerity politics is, for the time being, a necessary consequence of the current design of the EMU (in particular because of its focus on budget restraints and the absence of mechanisms to help its members absorb asymmetric shocks) rather than an unalterable economic law. The Maastricht criteria identified price stability, budget sustainability, exchange, and interest rate stabilisation as the basis on which convergence between EMU candidates was to be measured. This focus on financial convergence put fiscal discipline at the very core of the monetary union and ruled out internal redistribution as a means of redressing economic imbalances among EMU members. It thus put the whole burden of maintaining or restoring internal market equilibrium on internal adjustment (i.e. on devaluation, labour market deregulation, and welfare cuts) (Lintner, 2000/2007), with the consequence that growing pressure was put on the labour market (Dornbusch, 1996, p. 120). The indebted countries' declining GDPs and increased unemployment are therefore not mere side effects, but rather direct and intended consequences of EMU rules. If this has thus far gone unnoticed, it is only because of their lax application in the first decade of the common currency. It became evident after the violation of the Treaty's no bailout clause had to be politically balanced with the tough austerity measures imposed on indebted countries. ${ }^{7}$

As divergent as the pro- and anti-austerity narratives appear at first sight, both reveal the EMU as a political arrangement aimed to foster a specific, non-political vision of the EMU, in which market mechanisms rather than common economic and welfare policies 
are called on to reflect EMU members' economic performances, their relative wealth, and their welfare standards. It is an arrangement with unequally distributed, high political and social costs.

\section{Intergovernmental crisis management and distributive conflicts}

The current EMU financial rules impinge on the scope of action of its members' executive and legislative bodies such that key national tasks, such as labour market regulation, welfare provision, overall taxation burden, public property and public property alienation - in short: the amount and allocation of public expenditure in general - are at least substantially co-determined by organs that are not accountable to the direct addressees of national policies. And yet it is the latter who carry the burden of all decisions taken in this regard.

The current intergovernmental decision-making structure is unable to step in for the loss of democratic control over key national policies. Indeed, the opposite is true: now that Eurozone countries are split between lenders and borrowers, decision-making involves a power gap between partners who face each other in the double role of (putative) cooperators and (de facto) unequal competitors for their share of the financial resources (Habermas, 2015). Thus the current crisis (which the firm intervention of the ECB can only offset temporarily) is indeed a crisis of interpretation - mainly involving neo-liberal and Keynesian or neo-Keynesian economists, but with the significant participation of leading political figures, such as Schäuble (2010) and Padoan (Padoan \& van den Noord, 2012), and the European Commission under Barroso's presidency (European Commission 2011: 7; 2012: 2).

Beneath the ideological surface, however, there emerges the crudely 'material' dimension of the crisis and its management. In fact, Europeans are facing a crisis of economic and political interests, primarily due to the fact that the EMU's current rules and governance structures divide its participants into lenders and borrowers, debtfraught and savings-investing countries, involving them in a neo-mercantilist fight between export-oriented and import-'prone' economies. ${ }^{8}$ The precise distribution of roles in this comedy at any given time depends on countries' shifting positions relative to others. While Sarkozy's France was indeed on the 'tough' side at the time of the first Greek bailout due to its lending position, it is decisively on the 'lax' side when it comes to applying flexibility rules to the Commission's scrutiny of national budgets. Countries like Germany are more predictably on the tough side due to their clear-cut position as exporters of both capital and goods - in addition to their supposed 'culturally' embedded savings culture. ${ }^{9}$

The current governance structure would be acceptable (at least to the extent that output legitimacy is acceptable from a democratic standpoint) if decisions at the EMU level were still substantially consensual and EMU members were to seriously attempt to accommodate one another's priorities, as occurred (although not without controversy) in the case of Germany's and France's excessive deficits in 2003 (and as currently holds at the insistence of France and Italy with regard to their current deficit-to-GDP ratios, as regards its cyclical component). ${ }^{10}$

However, the crisis has decisively altered both the balance of power among EMU members and the readiness of public opinion and governments to cooperate for the 
sake of each other's legitimate needs and aspirations. The EMU's substantially intergovernmental character has sharpened the conflict between discipline- and growth-oriented Eurozone governments, that is, those who identify 'market discipline' (Hallerberg, 2010) and strict rule implementation (Schäuble, 2010; Stark, 2010) as conditions for the sustainability of the EMU, and therefore also for the political sustainability of the common currency, and those who instead locate the solution in economic growth at the expense of a more flexible interpretation of the budgetary rules. The governments of bailed out countries largely supported austerity politics, giving the impression that current legitimacy mechanisms, still based on the domestic accountability of national governments, were sufficient to ensure the legitimacy of the overall crisis management. Nevertheless, the common currency poses a vast number of interrelated ethical and political challenges that far transcend the simply technical matter of rule implementation and that raise more general questions about the desirable level of economic and political integration in a monetary union.

\section{The common currency as a dilemma concerning legitimacy}

The ethical questions at stake concern both the scope of democratic decision-making in the Eurozone and the reciprocal moral duties of EMU partners. The current arrangement reflects a double dilemma: on the one hand the rigidity of the rules reflects the need to prevent free riding in the absence of a central rule-enforcement authority, while on the other hand the domestic dimension of democracy in Europe compels political actors to spell out European arrangements in terms of national visions and interests, and therefore to assume a rather inflexible attitude in the conflict over the distribution of the costs of convergence among EMU partners. Reciprocal scepticism and blindness to one another's needs and legitimate interests is the obvious result of this kind of political construction.

Moreover, inasmuch as the EMU is designed to bind partners to a definite set of rules, it necessarily takes key decisions out of the hands of national institutions. At the same time, it does not provide for a similar legitimate decision-making mechanism at the EU or EMU level. The current mechanisms of euro governance therefore entail both a distributive conflict among the participants and an encompassing legitimacy deficit. ${ }^{11}$

Insofar as they have acted within the terms originally set up by the members, there is little (to no) doubt that the EMU, its institutions, and the means they have taken from 2008 onwards to counter the sovereign debt crisis are formally and legally legitimate. Indeed, all stipulations followed the contractual terms and formal rules freely agreed to from the signing of the Maastricht Treaty onwards. Formal decision-making rules have never been broken, and the treaties that established them have been properly ratified by national parliaments, or in any case approved in the manner foreseen by the EMU members' national constitutions.

However, EMU rules impinge on the powers of national governments to such an extent, and exert pressure on the national parliaments' legislative activity to such a degree, that their legitimacy must be reconsidered in the light of the European commitment to democratic decision-making. European citizens need to ask themselves which of the two is more important: an intergovernmentally shaped Union built around international treaties that take precedence over national democratic decision-making or democratic decisionmaking itself, and how this might be spelled out on a European scale. In any case, the 
EMU ought to shift from the kind of justification appropriate to intergovernmental, international treaties to that which is required in democratic systems.

As long as the conflict between the intergovernmental and the national democratic dimension of decision-making remains unresolved, there is the risk that any compromise on the content of the rules or their implementation will only temporarily appease the distributive conflict among member states, for the latter is built into the political design of the EMU as it currently stands. As Weale (infra) has pointed out, the EU - and in particular the EMU as a set of international agreements between member states - is a compound polity in which member states are required to make a credible commitment to comply with the terms of the inter-state contract. Member states' governments make commitments as representatives of their citizens, to which they are accountable in a democratic framework. Their commitments must therefore also be acceptable at the domestic level. This double commitment to European partners and domestic constituencies may lead to conflicts between the international and the domestic levels, thus undermining a government's credibility in the eyes of its partners or its acceptability to the domestic constituency. The latter is especially true since in European matters domestic legitimacy is by and large 'output legitimacy' insofar as it is tied up with the overall advantages of the international contract. The will of the national sovereign is thus likely to be in conflict with the inter-state rules to the extent that the latter are no longer able to secure a clear win-win situation for all participants in the contract. Moreover, since the inter-state contract severely limits the scope of action of all participating governments, the latter find themselves bound to rules that neither secure the well-being expected by citizens when they joined the contract nor allow governments to take steps to change the economic course. The greater the pressure faced by governments from their European partners, the more their internal legitimacy is likely to be undermined.

This would not represent a problem for democratic legitimacy if a mechanism of legitimation were to connect the implementation and - whenever necessary - the re-negotiation of the common rules back to a source of popular authorisation (either domestic or supranational). In such a case, both the rules and their ongoing consequences would be drawn back into a legitimacy-producing mechanism of popular will. But inter-state agreements have been negotiated so as to commit member states to rules that severely limit national sovereignty with regard to key domestic policies, while there is no democratic supranational source of legitimation in place to deal with the political and economic consequences of the rules' implementation. When an international agreement impinges on the competencies of national governments such that it poses severe limitations to the exercise of national autonomy, it seems reasonable that the criteria used to evaluate the legitimacy of such an agreement will resemble those that apply to the exercise of national political authority.

If the EMU is to meet the normative expectations of democratic constituencies, which are both the addressees of justification and the entities that authorise the functioning of the relevant institutions, it requires 'public' justification -that is, justification that appeals to all (Morgan, 2005, p. 33) and is discussed in a way that includes all who are subject to the institutions in question (Habermas, 1996, p. III, 3). 


\section{Paths towards new governance of the EMU}

Despite the need to approximate the democratic form of justification for the EMU, we need to acknowledge the reasons for its having been set up as an international treaty an obvious consequence of which is the intergovernmental structure of decisionmaking. European peoples are already organised into political communities with their own traditions and identities. They have their own economic interests and participate in the EMU in order to enhance their own well-being. Political debate still takes place by and large at the national level and focuses on national concerns and aspirations. Mechanisms of political legitimacy are likewise still national. The kind of consensus to be achieved among EMU partners must therefore take into account the preferences and long-term choices that different national democratic constituencies have made through the decades (i.e. what Habermas calls the 'values' of a historical society) (1996, p. 300). Moreover, the common rules impact differently on different countries because of the disparities among, and peculiarities of, participating members states. The idea that whatever decision is made must reflect a compromise among the partners must therefore be taken seriously. To a certain extent, EMU politics is and will remain a matter of international politics. In an international context, convenors must be able to reach a fair compromise between the values (and the material interests) at stake - and such a compromise is necessarily different from the kind of consensus that must be possible among citizens of a democratic constituency.

Nevertheless, since inflation targets, public debt and deficit targets, unemployment rates, poverty, and access to fundamental welfare services all depend to a certain extent on the implementation of the common rules, common decision-making requires a form of legitimation that is stronger than that which a purely intergovernmental process can achieve: a form of legitimation akin to that practiced in national democracies, and which allows the European peoples to restore, at the level of common decisionmaking, the sovereignty that their governments forsook when they subjected their choices to the common rules.

In sum, what is needed is a model of governance that:

(1) Allows for the co-ordination of national budgets so as to prevent free riding on other members' fiscal stability.

(2) Ensures the means to obtain compliance from member states.

(3) Allows participants to bring to bear their preferences as to the right balance between rigour and public spending, in order to account for their different preferences on the ways to achieve growth and fiscal stability.

(4) Grants the European peoples, who bear the consequences of collective decision-making, a level of communicative participation sufficient to allow them to effectively represent their interests and bring them to bear during the decisionmaking process, and to express their consent to, or dissent from, the decisions being made.

(5) Allows for debate that is sufficiently inclusive and decision-making that is sufficiently participative, such that the interests brought to bear are demonstrably generalisable and not strictly particular, that is, merely national.

(6) Rules out 'absolute losers' and permanent (national) minorities. 
(7) Compels participants to look for a balanced result that includes one another's legitimate interests as a condition for decision-making.

(8) Includes in the collective decision-making process the policies on whose implementation the common rules more directly impact at the national level, such as those concerning unemployment and access to fundamental welfare services.

In light of the current level of political conflict and mistrust in Europe, at the level of both public opinion and government, it seems vain, if not outright delusional, to expect deep reform of the EMU. From 2011 onwards, however, both the Commission and the Council set forth several drafts in this regard, making reasonable certain considerations about the steps that seem apt both for enhancing the political legitimacy of the EMU and for achieving the political values that the Union claims to acknowledge.

\section{(A) Re-politicising the rules}

In order to adjust to the consequences of the implementation of the common rules and the changing global economic and financial environment, these rules, and in particular the timing of their implementation, ought to be periodically rediscussed and renegotiated, including the short- and medium-term deficit-to-debt ratio and the pace at which the debt-to-GDP ratio ought to be reduced (for those countries that need to reduce it). Just as national parliaments periodically discuss budgetary laws, and governments suggest policies for growth and employment goals (or even inflation goals, as in the UK), so there ought to be a legislative process to establish similar objectives for the EMU.

\section{(B) Including welfare and employment parameters in the GSP}

In order to restore at the EMU level some of the competencies that national governments inevitably lose whenever they have a hard time abiding by budgetary rules, a number of common standards of poverty reduction, unemployment, and access to fundamental services (such as health) could be included in the 'convergence criteria' of the Growth and Stability Pact. Such standards would serve as a further component in the determination of the pace at which budgetary adjustment should be implemented for EMU member states. This idea is not new to the debate in Europe. Indeed, the integration of labour markets, the coordination of welfare mechanisms, the harmonisation of educational systems, workers' representation, etc., as well as fiscal coordination and common budgetary measures (i.e. transfers among member states) meant to amend the consequences of economic imbalances, were all evoked from the inception of the EMU onwards (Arfara, 2012; Buiter, Corsetti, \& Roubini, 1993; De Grauwe, 1996; Feldstein, 1992, 2010; Lintner, 2000/2007; Moravcsik, 2012). This highlights the widely acknowledged fact that the EMU is unthinkable without a substantial transfer of sovereignty in economic matters a transfer that has indeed already happened, although national governments and parliaments maintain a formal grip on their respective countries' economic levers.

It is worth noting that the need to converge on standards that are not purely budgetary would remain even if the rules of the Pact were to be steadily or temporarily softened, which is currently the most debated issue at the EU political level, and as is now the case in the evaluation of the deficit-to-GDP ratio and the debt-to-GDP reduction ratio 
(European Commission (2012)). Indeed, in a number of communications concerning possible steps towards EMU reform, even the European Commission has acknowledged the importance of the inclusion of social standards in the evaluation of economic policies (European Commission 2013a; 2013b).

'Flexibility', now eagerly discussed, is apt for alleviating the costs of convergence but will not overcome the legitimacy deficit (and it is highly doubtful that it actually fosters economic growth). As shown above, the Pact has been elaborated in order to impose on governments a politics of re-adjustment, so that national societies can improve competitiveness by means of internal devaluation and continued austerity measures. The rules determine the pace at which this is meant to happen, not the fact that it must be done. Therefore, restrictions on national welfare and the scope of national autonomy in determining politics against unemployment, poverty, access to fundamental welfare services - in short, the substantial curtailment of a government's ability to intervene on national well-being - will remain (unless the rules are softened such as to make them fully ineffective), as will distributional conflicts among EMU partners. The current struggle for the application of the rules of the Growth and Stability Pact is therefore apt for securing temporary relief for those governments (and nations) that currently find themselves under greater pressure to re-adjust, but it is not apt for solving the overall legitimacy problem. As for the current structure of EMU governance, EMU partners are condemned to negotiate the application of the common rules under conditions of continued political tension among nations - a condition that was by and large predicted well in advance (Feldstein, 1997, p. 61). There is thus an urgent need to complement the Growth and Stability Pact with standards that reflect the interest of European peoples in preserving, furthering, and maintaining democratic control over their own well-being.

\section{(C) Getting the European Parliament involved}

Decisions about these policy objectives could be made by means of a revised ordinary legislative procedure. ${ }^{12}$ Recently, the EP argued along these lines - albeit to a more limited extent - in the resolution of 24 June 2015, in which it claims that the convergence programmes containing the financial and reform priorities for EMU member states ought to be subject to the co-decision procedure in order to increase their democratic legitimacy. ${ }^{13}$

Some technical changes to the ordinary legislative procedure are needed, first and foremost with regards to its duration. ${ }^{14}$ Further changes could improve the democratic legitimacy of the EP as a representative of the European people: its composition is disproportional, and the Parliament indeed represents the European 'peoples' - not a European 'people' (which patently does not exist, even though a representation of European citizens in general might be necessary for the EMU to outgrow its mercantilist stage; see Costa, 2001). The still differing electoral mechanisms in the various member states and the ongoing national dimension of European elections must also be addressed, although the successful attempt during the 2014 electoral campaign to forge international alliances under the umbrella of common candidates for the Presidency of the Commission is a promising sign that European elections might acquire a more markedly supranational character in the future. 
To be sure, national interests still play an important role in the proceedings of the EP, especially as regards the Committees. ${ }^{15}$ However, increasing political discipline within political groups (Smith, 1995, p. 72), the formation of predictable minorities and majorities along classical ideological boundaries - and the tendency towards bipartisanship among the two major groups (seemingly a consequence of the rules of the co-decision procedure) (Kreppel, 2002, p. 124) recommend the substantive inclusion of the EP in decision-making on macroeconomic policies. ${ }^{16}$ This speaks in favour of the presence of a predictable political (instead of simply national) divide in the EP, which would strengthen the EP's ability to offer a supranational political arena in which macroeconomic policies can be discussed in a way that moves beyond national interests. Moreover, although inter-group cooperation seems easier in some policy areas than others (such as labour-related issues) (Kreppel, 2002, p. 170), the two major groups in the EP are evidently capable of mediating between different positions in order to find a commonly acceptable and institutionally viable solution.

\section{(D) Involving national parliaments}

As mentioned above, the current intergovernmental approach to the EMU becomes more plausible once we consider that member states already have their own macroeconomic 'traditions', their own stabilised 'preferences' concerning rigour and public spending, inflation rates, etc., and their own long-term 'preferences' on public welfare. It is unlikely that the peoples of Europe will be ready to transfer sovereignty to the supranational level and to forsake their own macroeconomic and welfare paths - at least for the foreseeable future. The ordinary legislative procedure grants the EP and the Council equal weight in determining the final outcome of legislation, with the Council acting as a second chamber in which governments, and therefore the economic and social interests of member states, are represented. And yet, despite the desirability of strengthening the communitarian level of political debate on macroeconomic and welfare policies, decisions in this regard cannot plausibly be delegated to the ordinary legislative procedure altogether. The deeper involvement of national parliaments could help preserve a reasonable degree of popular control, transparency, and publicity in a way that does not impair EU decision-making. The reinforced inter-parliamentary cooperation currently promoted by the EP could be used to implement an ongoing exchange of opinions between national parliaments and the EP, both ex-ante and in the course of the legislative process. ${ }^{17}$ However, in order to preserve the (reasonable) influence of national electorates on European decision-making processes, the involvement of national parliaments could be brought in line with the idea of a qualified 'blocking coalition' with regard to decisions made about the relevant rules at the EU level.

\section{(E) Redistributing the costs of convergence?}

The implementation of social standards in the convergence criteria can be undertaken either via national budgets (i.e. by means of 'flexibility') or via a common European budget (i.e. through intra-European transfers).

The first option is currently being discussed at a scholarly level, with important suggestions coming from inside the Commission. ${ }^{18}$ It consists in discounting social expenditures 
from the calculus of the macroeconomic convergence criteria on the basis of an EU-wide benchmarking of social and employment standards. Speaking in favour of this kind of proposal is the fact that it does not imply a transfer union and might therefore be acceptable even to those governments and public opinions that are less prone to integrating elements of mutuality into the EMU. What speaks against it is the fact that it does not contribute much to smoothing out the edges of the process of convergence, although it eases short-term pressure on public budgets.

The second, politically more interesting and economically more sensible option involves precisely those elements of risk sharing and pooling (in the direction of a more proper transfer union) that most governments seem to reject, and therefore appears less politically viable. It is nevertheless interesting to the extent that it could possibly prompt a 'convergence of economic interests' among EMU partners, thus helping to promote the search for a 'supranational European interest' and precluding free riding: if the 'costs of convergence' that any fellow citizen has to bear in order for his/her country to comply with the common rules are in the end to a certain extent also mine, I will have an incentive to look for rules that coincide with my fellow citizens' legitimate interests and needs, and that therefore more equally distribute the costs and benefits of that same convergence.

Several suggestions have already been made in this respect. The most widely discussed model envisages a mechanism of fiscal transfer inside the Eurozone in the form of a kind of unemployment insurance; it aims to uphold aggregate demand, prevent pro-cyclical fiscal policies, and reduce uncertainty regarding countries' financial solvency in case of a downturn in the economic cycle (Andor, 2014; Dullien, 2014). Unemployment insurance of this sort would also reduce cyclical divergence among the national economies of participating countries to the extent that it would contribute to limiting regional booms and downturns (Dullien, 2013). ${ }^{19}$ Beyond technical debates on the specifics of this kind of insurance - concerning for instance its financing base (DG Employment, 2013; Pisani-Ferry, Vihriälä, \& Wolff, 2013), its 'triggers' (i.e. the economic conditions that would set off the transfers) (Beblavý \& Maselli, 2014; Dolls, Fuest, Neumann, \& Peichl, 2015), and its precise interaction with national insurance schemes (Beblavý \& Maselli, 2014; Depla, 2012) - there looms a key political question as to its net re-distributional effect: should it be a transfer mechanism, or should its net effect be nil in the medium term? Studies show that in both cases such a mechanism would have beneficial effects on the overall convergence process.

Equally controversial, however, is its dampening effect on macroeconomic divergence, for this would seem to require a shift in how members conceive of macroeconomic convergence: from a purely economic process in which national virtues are glorified and national vices scorned to a political process of mutual cooperation grounded in a basis of fairness. In any case, decisions on these matters must comply with the standards of political legitimacy depicted above.

\section{Conclusion}

Beyond the widely discussed technical deficiencies of the common currency, there lies a political misstep: the EMU has been conceived in such a way as to leave economic relations among member states - and thus also differences in relative political weight unaltered. Thus the EMU was bound from the start to acquire a combative rather than a 
cooperative character. In the context of this conception of the EMU, it is obvious that political legitimacy was not an issue. In times of economic hardship, which have been exacerbated by the rules of the EMU, the political economy of the weaker member state is sacrificed on the altar of the uncooperative logic of the monetary union. Two traditional gaps reinforce this original sin (or political ill will) in the structure of the EMU: the concern for preventing free riding in the absence of a central rule-enforcement authority, and the fact that the domestic dimension of democracy in Europe compels political actors to spell out European arrangements in terms of national visions and interests. All this has caused decision-makers to fall prey to a largely inflexible attitude in the conflict over distribution of the costs of convergence among EMU partners.

Because the EMU is designed to bind partners to a definite set of rules, it necessarily takes key decisions out of the hands of national institutions. At the same time, it does not provide for a similarly legitimate decision-making mechanism at the EU or EMU level, and is therefore unable (and its members unwilling) to compensate for the loss of democratic control on key national policies. Instead of making the EMU an instrument of collective, Europe-wide economic self-determination through mutual cooperation, Eurozone countries are split between lenders and borrowers, exporters and importers, debtors and creditors. In its current form, the EMU strengthens the power gap between partners who face each other in the dubious double role of putative cooperator and de facto unequal competitor.

Considering the limitations that European rules impose on national economic and social policies, and in the interest of restoring democratic self-determination, the EMU ought to shift from the kind of justification that is appropriate to a largely intergovernmental model of governance based on international treaties to that which is appropriate to a democratic system. A model of governance is needed that: (1) prevents free riding on certain members' fiscal stability; (2) ensures the means to obtain compliance from member states; (3) allows participants to bring their preferences to bear in terms of fundamental macroeconomic choices; (4) secures for European peoples a level of communicative participation similar to that enjoyed in national democracies; (5) structures decisionmaking so as to allow for the formation of an interest that is both generalisable (in Habermasian terms) and not purely national; (6) rules out 'absolute losers' and permanent (national) minorities; (7) 'compels' participants to look for balanced results that coincide with one another's legitimate interests; and (8) preserves sovereignty on social policies at the European level even where sovereignty is eroded by the common rules at the national level.

A possible (although presently unlikely) implementation of the above criteria consists in 're-politicising' the rules, that is, feeding them into a political process, such as the ordinary legislative procedure, aimed at periodically determining the macroeconomic objectives of the Eurozone (or the Union as a whole). Alongside such objectives, common social policy objectives - including welfare and employment objectives - could also be discussed and subject to common decision-making. Considering the paramount role played by national democracies both as loci of democratic self-determination and in implementing and specifying macro-economic and social policies and traditions on the European stage, the inclusion of national parliaments in more than a consultative capacity should be taken into account - for instance in the form of a 'blocking coalition' of national parliaments. Finally, mechanisms that allow for the pooling of the risks and burdens inherent in the 
convergence process - and thus for true convergence at the level of economic interest can achieve the double effect of smoothing out the edges of the economic cycle and strengthening the cooperative will of Europe's governments.

\section{Notes}

1. See Wickens (2010) for a detailed analysis.

2. In fact, it is even doubtful that price and wage flexibility plays such a key role in the absorption of asymmetric shocks. Labour mobility might play a major role instead (Blanchard \& Katz, 1992). If this is true, a currency union will only be possible given consistent inter-European labour mobility.

3. As a matter of fact, several scholars have given timely warnings to the effect that this would be the most likely outcome of the EMU as it has been conceived and implemented (see for instance Buiter et al., 1993; De Grauwe, 1996).

4. It is indeed doubtful whether they do now, even after the recent governance reforms. See Scharpf (2013, p. 16-17) for a thorough analysis.

5. See Eurostat (http://ec.europa.eu/eurostat/tgm/table.do?tab=table\&init=1\&language= en\&pcode=teina225\&plugin=1).

6. https://data.oecd.org/trade/current-account-balance.htm.

7. Portugal's former Prime Minister, Passos Coelho, brought this to the foreground when at a conference organized by the daily Diário Económico on 25 October 2011 he made clear that his country's way out of the crisis consisted straightforwardly in 'getting poorer'.

8. Busch has aptly characterised the EMU as a 'system of competing states' (Wettbewerbsstaaten) (Busch, 2009, p. 8).

9. See Abreu et al. (2013, p. 34-39) for a more detailed analysis.

10. For a brief overview of the lax application of the EMU common rules, see Wyplosz (2011, p. 21).

11. For an overview of the debate on the EU democratic deficit prior to the euro, see Bellamy and Castiglione (2000, p. 66-68).

12. Modifications would be required first and foremost insofar as rejection by the Parliament on second reading cannot be an option. Modifications regarding the role of the Commission in the legislative procedure could be taken into account, especially in the case of conciliation.

13. For an alternative vision, see Busch $(2012$, p. 40), who recommends a 'supranational, elected economic government' for the Eurozone in which a reformed EP, elected on the basis of the equal weight of all voters, would act as one chamber, while states would be represented in the Council as a second chamber. Busch's model does without the involvement of national parliaments and reserves for the Commission the role of 'determining the direction of members states' budgetary policy'.

14. The bulk of the procedures undertaken during the seventh parliamentary term took no less than 17 months (http://epthinktank.eu/2014/11/26/european-parliament-facts-and-figures/ ep-facts-and-figures-fig-19/).

15. National interests weigh deeply on the EP. For instance, national delegations might be overrepresented in committees when the impact of those committees on their own countries' legislation is particularly relevant. Conversely, committee members often tend to represent the orientations of their own national delegations. In more general terms, the dimensions of a national delegation have a relevant impact on a political group's overall orientation (Whitaker, 2011, p. Ch. 4, 7). Moreover, MEPs are inclined to follow the indications of their own national groups whenever those groups' positions conflict with their political groups at the $E P$, although this seldom occurs. In fact, party cohesion has increased over time, and voting behaviour usually follows the left-right distinction (Hix, Noury, \& Roland, 2007). See also De Angelis (2013).

16. Indeed, similar suggestions have already been proposed at the institutional level, although in a different context (van Rompuy, 2012, p. 16, 2013, p. 13; European Commission 2012: 35; Junker, 2015, p. 17). 
17. See in particular the EP 'Resolution of 16 April 2014 on relations between the European Parliament and the national parliaments' (2013/2185(INI)).

18. See European Commission (2013b). The key idea is to scale up the Employment and the Social Protection Performance Monitors into a scoreboard of indicators - analogous to the MIP scoreboard (Regulation (EU) 1176/2011) - to evaluate member states' social performances.

19. A mechanism addressing cyclical divergences more specifically has been proposed by Enderlein, Guttenberg, and Spiess (2013).

\section{References}

Abreu, A. et al. (2013). A crise, a troika e as alternativas urgentes. Lisboa: Tinta da China.

Andor, L. (2014). Basic European unemployment insurance - The best way forward in strengthening the EMU's Resilience and Europe's Recovery. Intereconomics, 49(4), 184-189.

Arfara, G. (2012). Per salvare l'Euro i forti sono condannati a finanziare i deboli. Limes, 4(3), 17-24.

Baimbridge, M., Burkitt, B., \& Whyman, P. B. (2012). The Eurozone as a flawed currency area. The Political Quarterly, 83(1), 96-107.

Beblavý, M., Maselli, I. (2014). An Unemployment Insurance Scheme for the Euro Area: As imulation exercise of two options (Report No. 98/December). CEPS Special Report.

Bellamy, R., \& Castiglione, D. (2000). The uses of democracy. In E. O. Eriksen \& J. E. Fossum (Eds.), Democracy in the European Union. Integration through deliberation? (pp. 65-84). London: Routledge.

Blanchard, O. J., \& Katz, L. F. (1992). Regional evolutions. Brookings Papers on Economic Activity, 1992 (1), 1-75.

Buiter, W. H., Corsetti, G., \& Roubini, N. (1993). Excessive deficits: Sense and nonsense in the treaty of Maastricht. Economic Policy, 8(16), 58-100.

Busch, K. (2009). Weltwirtschaftskrise und Wohlfahrtsstaat. Berlin: Friedrich-Ebert-Stiftung.

Busch, K. (2012). Is the Euro failing? Berlin: Friedrich Ebert Stiftung.

Costa, O. (2001). Le Parlement européen, assemblée délibérante. Bruxelles: Éditions de I'Université de Bruxelles.

De Angelis, G. (2013). Enhancing fundamental rights control in Europe. The European parliament's scrutiny of member states. In G. De Angelis \& P. Barcelos (Eds.), The long quest for identity. Political identity and fundamental rights protection in the European Union (pp. 87-134). Frankfurt a. M.: Peter Lang.

De Grauwe, P. (1996). Monetary union and convergence economics. European Economic Review, 40(35), 1091-1101.

De Grauwe, P. (2012). The economics of monetary union. Oxford: Clarendon Press.

Depla, J. (2012). A Euro-wide conditional unemployment insurance. Paper prepared for the seminar on EU Level Economic Stabilisers. Brussels, 2 July.

DG Employment, Social Affairs and Inclusion. (2013). Paper on automatic stabilizers. Brussels: European Commission.

Dinan, D. (2010). Ever closer union. An introduction to European integration. Basingstoke: Macmillan.

Dolls, M., Fuest, C., Neumann, D., \& Peichl, A. (2015). An unemployment insurance scheme for the Euro area? A comparison of different alternatives using micro data (CESifo Working Paper No. 5581). Munich: CESifo.

Dornbusch, R. (1996). Euro phantasies. Foreign Affaires, 75(5), 110-124.

Dullien, S. (2013). A European unemployment insurance as a stabilization device: Selected issues. Corrected version from 11 December 2013. Brussels: European Commission.

Dullien, S. (2014). The macroeconomic stabilisation impact of a European basic unemployment insurance scheme. Intereconomics, (4/2014), 189-193.

Enderlein, H. (2010). Krise in der Euro-Zone. Aus Politik und Zeitgeschichte, B43, 7-12.

Enderlein, H., Guttenberg, L., \& Spiess, J. (2013). Blueprint for a cyclical shock insurance in the Euro Area. Paris: Notre Europe. 
van Esch, F. A. W. J. (2014). Exploring the Keynesian-Ordoliberal Divide. Flexibility and Convergence in French and German Leaders' Economic Ideas During the Euro-Crisis. Journal of Contemporary European Studies, 22(3), 288-302.

Esser, J., \& Schroeder, W. (1999). Modell deutschland: von der Konzertierten Aktion zum Bündnis für Arbeit. Aus Politik und Zeitgeschichte: Beilage zur Wochenzeitung Das Parlament, B37, 3-12.

European Central Bank. Monetary policy and inflation differentials in a heterogeneous currency area. Retrieved from www.ecb.int/pub/pdf/other/pp61_77_mb200505en.pdf

European Commission (2011). Green Paper on the Feasibility of Introducing Stability Bonds. COM (2011) 818 final. Brussels: European Commission.

European Commission (2012). A blueprint for a deep and genuine Economic and Monetary Union. Brussels: Communication from the Commission. 30.11.2012, COM(2012) 777 final/2.

European Commission (2013a). Towards Social Investment for Growth and Cohesions. Communication from the Commission, 20.2.2013. $\operatorname{COM}(2013) 83$ final.

European Commission (2013b). Strengthening the social dimension of the EMU. Brussels: 2.10.2013, $\operatorname{COM}(2013) 690$ final.

Feldstein, M. (1992). Europe's monetary union; the case against EMU. The Economist, 13, 23-26.

Feldstein, M. (1997). EMU and international conflict. Foreign Affairs, 76(6), 60-73.

Feldstein, M. (2010). The Euro's fundamental flaws. The International Economy, 24(2), 11-12.

Godley, W. (1992/1997). The hole in the treaty. In J. Shahin \& M. Wintle (Eds.), The idea of a United Europe. Political, economic and cultural integration since the Fall of the Berlin Wall (pp. 173-177). Houndsmill: Macmillan.

Guérot, U. (2013). Germany debates political union. In N. Walton \& J. Zielonka (Eds.), The new political geography of Europe (pp. 21-27). London: European Council on Foreign Relations.

Habermas, J. (1996). Between facts and norms. Boston, MA: The MIT Press.

Habermas, J. (2015, June). Warum Merkels Griechenland-Politik ein Fehler ist. Süddeutsche Zeitung, 22. Retrieved from http://www.sueddeutsche.de/wirtschaft/2.220/europa-sand-im-getriebe-1. 2532119

Hallerberg, M. (2010). Fiscal federalism reforms in the European Union and the Greek crisis. European Union Politics, 12(1), 127-142.

Hix, S., Noury, A. G., \& Roland, G. (2007). Democratic politics in the European Parliament. Cambridge: Cambridge University Press.

Henkel, H.-O. (2010, December). Towards a separate future. The European.

Joerges, C. (2012). Recht und Politik in der Krise Europas. Merkur, 66(11), 1013-1024.

Junker, J.-C. (2015). Completing Europe's Economic and Monetary Union. A Report by Jean-Claude Junker in close cooperation with Donald Tusk, Jeroem Dijsselbloem, Mario Draghi and Martin Schulz, June 2015.

Kerber, M. (2012). La strategia dello squilibrio. Limes, 4(3), 77-82.

Kirsch, G. (2010). Die Euro-Kise ist nicht nur eine Währungskrise. Aus Politik und Zeitgeschichte, 43, 3-7.

Kreppel, A. (2002). The European parliament and supranational party system. A study in institutional development. Cambridge: CUP.

Kundnani, H. (2012). Scontro di civiltà in Europa. Limes, 4(3), 9-16.

Lintner, V. (2000/2007). Controlling monetary union. In C. Hoskyns \& M. Newman (Eds.), Democratizing the European Union (pp. 93-116). New Brunswick: Transaction Publishers.

Moravcsik, A. (2012). Europe after the crisis. How to sustain a common currency. Foreign Affairs, 91(3), 54-68.

Morgan, G. (2005). The idea of a European superstate. Public justification and European integration. Princeton: Princeton University Press.

Mundell, R. A. (1961). A theory of optimum currency areas. The American Economic Review, 51(4), 657665.

Ohr, R. (2012). Wie viel Euro braucht Europa? Aus Politik und Zeitgeschichte, 13, 23-28.

Padoan, P. C., \& van den Noord, P. (2012). Is austerity going too far? Structural reforms and the Debt Trap. In F. Allen (Ed.), Governance for the Eurozone (pp. 103-114). Philadelphia, PA: FIC Press.

Pisani-Ferry, J., Vihriälä, E., \& Wolff, G. (2013). Options for a Euro-area fiscal capacity. Bruegel policy contribution, N. 1/2013. Bruegel: Bruegel. 
Pomés, J. (2012). Senza mea culpa la Spagna resta al palo. Limes, 4(3), 197-202.

Richter, H. (2012). Die politische Kultur Griechenlands. Die politische Meinug, 508, March 2012, 51-58. van Rompuy, H. (2012). Towards a genuine economic and monetary union. Brussels: European Council. van Rompuy, H. N. (2013). Towards a genuine Economic and Monetary Union. Towards an integrated economic policy framework: state of play of consultations. Presentation by President Herman Van Rompuy to the European Council, 28 June 2013.

Sarrazin, T. (2012a). Europa braucht den Euro nicht. Munich: DVA.

Sarrazin, T. (2012b). Lei è italiano? Continui, prego!. Limes, 4(3), 83-88.

Scharpf, F. W. (2013). Political legitimacy in a non-optimal currency area (PPIfG Discussion Paper, 13/ 15). Köln.

Schäuble, W. (2010). Beistand unter Bedingungen für eine stabile Europäische Wirtschafts- und Währungsunion. Ifo-Schnelldienst, 64(3), 3-6.

Smith, J. (1995). The voice of the people. The European parliament in the 1990s. London: The Royal Institute of International Affairs.

Stark, J. (2010). Der Euro braucht striktere Regeln. Ifo-Schnelldienst, 64(3), 6-9.

Tilford, S. (2010). How to save the Euro. London: Centre for European Reform.

Whitaker, R. (2011). The European parliament's committees. National party influence and legislative empowerment. London: Routledge.

Wickens, M. (2010). Is the Euro the success that everyone seems to think? Open Economic Review, 21 (1), 183-185.

Wyplosz, C. (2011). Fiscal rules: Theoretical issues and historical experiences. Paper read at the NBER conference on Fiscal Policy after the Financial Crisis, Milan. 12-13 September.

Young, B. (2014). German ordoliberalism as agenda setter for the Euro Crisis: Myth trumps reality. Journal of Contemporary European Studies, 22(3), 276-287. 